The Historical Fournal, 44, 3 (2001), pp. $825^{-844}$ (C) 200 I Cambridge University Press DOI: гогі 7 /Soor8246Xor 002035 Printed in the United Kingdom

\title{
BLACKSHIRTS, BLUESHIRTS, AND THE SPANISH GIVIL WAR
}

\author{
JOHN NEWSINGER \\ Bath Spa University College
}

\begin{abstract}
The object of this review is to examine recent developments in our understanding of Oswald Mosley's Blackshirts, of Eoin O'Duffy's Blueshirts, and of British and Irish participation in the Spanish Civil War. It argues that fascism can be understood as having three possible phases of development and considers British and Irish fascism from that standpoint. Debates about the nature of British fascism are considered, its attitude towards violence, towards anti-Semitism, towards women, and towards the coming of the Second World War. The review considers the reasons for the movement's failure. It goes on to examine the debate as to whether or not there actually was an Irish fascism in the I93os. Finally, it discusses recent work on British and Irish participation in the International Brigades and on the performance of O'Duffy's volunteers in Spain.
\end{abstract}

'We really know very little about British fascism', wrote Robert Skidelsky just over a quarter of a century ago. ${ }^{1}$ If this was the case with British fascism, it was even more true of the disputed Irish version, Eoin O'Duffy's Blueshirts. While Maurice Manning's study, The Blueshirts, first published in $197 \mathrm{I}$, had made an impressive start to the mapping of the terrain, few, until quite recently, showed any interest in proceeding further. ${ }^{2}$ And much the same can be said with regard to the study of British and Irish participation in the Spanish Civil War. There were various memoirs, some of considerable interest, and a number of partisan histories (Bill Rust's I 939 Britons in Spain is a good example of the limitations of this genre), but really the work remained to be done. ${ }^{3}$ What we shall attempt here is an overview of the development of historical research into these three related and overlapping areas, focusing, in particular, on more recent publications.

\section{I}

One preliminary step is necessary. The definitional problems posed by generic fascism have long exercised historians and political scientists. There has been a somewhat futile search for the 'fascist minimum', for the discovery of those components that are essential if a movement or organization is to be counted as genuinely fascist. ${ }^{4}$ The weakness of this

${ }^{1}$ Robert Skidelsky, Oswald Mosley (London, i98 I), p. 31 7. First published in I975.

${ }^{2}$ Maurice Manning, The Blueshirts (Dublin, I971).

${ }^{3}$ Bill Rust, Britons in Spain (London, I 939).

${ }^{4}$ For an interesting discussion see Roger Eatwell 'On defining the "fascist minimum": the centrality of ideology', Fournal of Political Ideologies, I (r996), pp. 303-19. The best critique of this 
ideological approach to the subject is that it does not adequately explicate the developmental history of fascist movements. It focuses on the varieties of butterfly rather than the stages of development that the genus can go through. What I would argue for is a more dynamic account of the fascist phenomenon, an account that can only briefly be rehearsed here.

Fascist movements can pass through three distinct phases of development: first, the small, hardcore fascist group, bound together by a shared ideology and devotion to a leader; second, fascism as a mass movement, when the hardcore group becomes the centre of a movement with real social weight; and third, there is fascism in power, when it becomes the party of the state. Most fascist organizations do not go beyond the first phase and many disappear leaving scarcely a mark on the body politic. British politics, since the I 920 , has been, and still is, littered with such organizations. Some, in the right conditions of social, political, and economic crisis, make the transition to mass movement. Significant sections of the population, usually members and supporters of the traditional conservative parties, rally to their standard in a desperate attempt to secure a solution to their problems, a remedy of their grievances. Such mass movements pose a serious, sometimes fatal, threat to liberal democracy and to the left. And lastly, there are only two instances of fascist organizations achieving state power without outside assistance, Italy and Germany. There have, of course, been other occasions where fascist organizations have been incorporated into more traditional conservative authoritarian or military regimes, for example, the Franco regime, but their provenance remains conservative rather than fascist.

One of the advantages of this approach is that it avoids the problem of having to identify a fascist minimum that is appropriate both for the Nazis, who went through all three stages of development, and for the varieties of British fascism that fortunately did not. Indeed, from this point of view, the fascist organizations that Roger Griffin has characterized as 'abortive', can be better seen as pupae. ${ }^{5}$ They are certainly more typical of the phenomenon than either Italian fascism or German Nazism. What was to give fascism in many countries a greater menace than their domestic success actually warranted was the example provided first by Mussolini and, later, by Hitler. They showed what might happen.

One other factor is crucial to an understanding of fascism: its relationship with traditional conservatism. While fascism was always inimical to the labour movement and the left, it had a much more ambivalent relationship with the conservative right. Certainly individual socialists embraced fascism (Mussolini is the most prominent example, and Mosley, perhaps, another) and the fascists, on occasions, borrowed socialist rhetoric, arguments, and policies. Nevertheless, fascism, as such, was hostile to the organized left and promised its destruction. Its relationship with the conservative right was much more problematic, sometimes ferociously hostile, but in the end looking for an understanding, an arrangement with the conservative elites. For the conservative elites, the fascists sometimes appeared to be a useful club; this certainly seems to be the way that Lord Rothermere, for example, regarded the British Union of Fascists (BUF), at least for a while. In Robert Benewick's words, he seems to have regarded the BUF as

approach is provided by Robert Paxton in his 'The five stages of fascism', fournal of Modern History, 70 ( 1998), pp. I-23. My own preference, as will become clear, is for three stages.

${ }^{5}$ See the discussion in Roger Griffin, The nature of fascism (London, I991), pp. I I6-42. This includes a brief discussion of Mosley's British Union of Fascists. 
'the armed wing of the Conservative Party' ${ }^{6}$ Once the fascists assumed the proportions of a mass movement then their relationship with the traditional conservatives inevitably changed. It is important to remember in this respect that both Mussolini and Hitler were installed in power by conservatives, as members of conservative-dominated coalition governments. In Italy and Germany, the fascists were to become the senior partners; elsewhere they were used and then dispensed with. ${ }^{7}$

I I

As far as the historiography of the British Union of Fascists is concerned, it has been dominated by Sir Oswald Mosley's attempt to rewrite the history of the I93os. This involved emphasizing his role as a constructive statesman, whose voice went unheard, playing down the anti-Semitism and pro-Nazism of the movement he led, and casting himself and his followers as the victims of a great wartime injustice.

His autobiography, My life, and his second wife Diana's autobiography, A life of contrasts, both works of consummate mendacity, that nevertheless received considerable acclaim when first published, actually succeeded in setting the agenda. ${ }^{8}$ This agenda was to a considerable extent followed by Robert Skidelsky in his major academic biography, Oswald Mosley. Skidelsky argued quite seriously that Mosley's political life was informed by an unceasing quest for a 'land fit for heroes'. He was driven by concern for ordinary people, by the desire to improve their lives. His purpose was always honourable, indeed commendable, even if he had unfortunately put himself beyond the pale with his embrace of fascism. There is a sense of tragedy; that Mosley's great gifts were lost and the contribution he could have made to national well-being was thrown away. Skidelsky certainly criticizes Mosley, but more for the waste of his talents, rather than for what he embraced. As far as his fascism is concerned, the tone of the biography is too often apologetic, too often has the appearance of being a plea in mitigation, and sometimes even a statement for the defence.

One particular example can illustrate this. Skidelsky acquits Mosley of the charge of treason during the Second World War, arguing that he was not interned for anything he had done, but for what he might have gone on to do. He then proceeds to narrow this 'might have done' down to collaboration after Britain had surrendered. This could not possibly have been treason because the country would no longer have been at war. To argue that collaboration amounted to treason is according to Skidelsky 'obviously absurd and quite unhistorical'. He goes on to use the example of Konrad Adenauer as proof of this. Was Adenauer a traitor for working with the Allies after 1945 ? Obviously not. This is really quite grotesque. The distressing implication of Skidelsky's argument is that a collaborationist government in which Mosley participated would have been some sort of liberal democracy rather than the authoritarian fascist regime that he had advocated throughout the thirties. What would have been the fate of British Jews under

${ }^{6}$ Robert Benewick, Political violence and public order (London, I969), p. 99.

7 For a useful collection discussing fascist-Conservative relations see Martin Blinkhorn, ed., Fascists and Conservatives (London, i 990). See also Carl Levy, 'Fascism, national socialism and Conservatives in Europe, I9I4-I 945 : issues for comparativists', Contemporary European History, 8 ( I 999), pp. 97-I 26.

${ }^{8}$ Oswald Mosley, My life (London, I 968); Diana Mosley, A life of contrasts (London, I 977). See also the chapter on her beloved 'Kit', her personal nickname for Mosley, in Diana Mosley, Loved ones (London, I985), pp. I 55-205. 
such a regime? What would have been the fate of the British left and of the trade union movement? Skidelsky does not even consider these rather elementary questions. Rather than a comparison between Mosley and Adenauer, Quisling, Pavelic, and Déat spring more readily to mind. Skidelsky is singularly reluctant to put Mosley in their company. Mosley himself, it has to be said, was not so scrupulous either before or after the war. ${ }^{9}$

There is also another possible 'might have done' that Skidelsky does not seriously consider. What would have been the BUF's stance in the event of a German invasion. Certainly some BUF members would have fought the invaders, but most British fascists of that mind had already enlisted. There were good grounds for believing that the BUF would have worked for surrender under the guise of peace, at the same time as continuing its efforts to whip up anti-Semitism. Skidelsky played down the extent to which Mosley condemned the war as a Jews' war, as a war fought not in the interests of the British Empire but on behalf of international Jewry, as a war fought to make Britain 'fit for Hebrews to live in'. British Jews were being set up as ideal scapegoats in the event of defeat by the BUF and there can be no serious doubt that a collaborationist government that included Mosley would have engaged in and encouraged active persecution. Indeed, in the circumstances, far from the internment of Mosley and his followers being 'in the highest degree odious', it seems to have been an elementary precaution for the public good. ${ }^{10}$ Skidelsky even finds excuses for William Joyce; ' a man of rare abilities twisted out of shape by one of the innumerable tragedies of our century'. ${ }^{11}$ One's sympathy is perhaps lessened by the realization that the tragedy in question was Irish independence.

There has, of course, been a large body of work published on the BUF since the appearance of Skidelsky's biography. Indeed, the BUF has received considerably more attention than the electorally much more important Liberal Party in the same period. The histories of the BUF by Colin Cross and Robert Benewick both preceded Skidelsky, but since then major studies by D. S. Lewis and Richard Thurlow have appeared along with a number of more limited investigations into the BUF in the West Midlands and the East End of London. ${ }^{12}$ The BUF has also figured prominently in a number of collections on British fascism and the British right and scholarly articles still regularly appear in academic journals. ${ }^{13}$ Moreover, at the time of writing, Thomas Linehan has yet another history of the BUF forthcoming. ${ }^{14}$ What is proposed here is to look at what this growing body of work has to say about a number of particular issues: the

${ }^{9}$ Skidelsky, Mosley, pp. $45^{2-3}$.

10 For an opposing view see A. W. Brian Simpson, In the highest degree odious (Oxford, I992).

11 Skidelsky, Mosley, p. 343.

12 Colin Cross, The fascists in Britain (London, I96I); Benewick, Political violence; D. S. Lewis, Illusions of grandeur: Mosley, fascism and British society, I93I-I98I (Manchester, I987); Richard Thurlow, Fascism in Britain: a history, 19I8-1985 (Oxford, I987); John D. Brewer, Mosley's men: the British Union of Fascists in the West Midlands (Aldershot, I984); Thomas P. Linehan, East London for Mosley: the British Union of Fascists in east London and south-west Essex, 1933-1940 (London, I996).

13 Kenneth Lunn and Richard Thurlow, eds., British fascism (London, I930); Tony Kushner and Kenneth Lunn, eds., Traditions of intolerance (Manchester, I989); Tony Kushner and Kenneth Lunn, eds., The politics of marginality (London, I99o); Michael Cronin, ed., The failure of British fascism (London, I 996). Among the most important articles on the BUF are: Steven Cullen, 'The development of the ideas and policy of the British Union of Fascists', Fournal of Contemporary History, 28 ( I 993), pp. I I 5-36; G. C. Webber, 'Patterns of membership and support for the British Union of Fascists', Fournal of Contemporary History, ig (i984), pp. 575-6o6; P. M. Coupland, 'The Blackshirted utopians', Journal of Contemporary History, 33 ( I 998 ), pp. 255-72.

14 Thomas Linehan, British fascism, I9I8-I939 (Manchester, forthcoming). 
responsibility for violence, the BUF's anti-Semitism, its attitude towards, and involvement of, women, and lastly the reasons for its failure to make the transition to mass movement.

The questions of violence and anti-Semitism are closely related, but an effort will be made to separate them out here. With regard to the use of violence, the claim made by Mosley himself was that it was only ever used by the BUF in self-defence. He established the BUF's paramilitary Defence Force 'as the only way to defeat the highly-organised Communist guerrillas' who were trying to wreck his meetings. With an eye to Vietnam, he claims that they were engaged in a successful battle with communist guerrillas 'who were prototypes of those who have since appeared in many different parts of the world'. He did admit that he was reverting to type, becoming 'half soldier and half politician', but went on to claim somewhat extravagantly that ' $[\mathrm{t}]$ he blackshirt movement in the thirties was the only guarantee of free speech in Britain'. ${ }^{15}$ One should not take this too seriously. Skidelsky, for his part, roundly places the blame for political violence in the twenties and thirties on the Communist Party. This is a gross oversimplification that, moreover, does not take account of the changes in the party line over this period, a vital factor in Communist Party historiography. Skidelsky does acknowledge, however, that Mosley's decision to call himself a fascist 'in the inflamed conditions of the I 93 os was a provocation too many'. He was 'deliberately identifying himself with a movement which rightly or wrongly, was regarded with peculiar abhorrence by all left-wing organisations'. ${ }^{16}$ The words 'rightly or wrongly', it has to be said, appear far too often in Skidelsky's biography. More to the point, left-wing abhorrence of a movement that would have banned their organizations, imprisoned their leaders and activists, and established a dictatorial government hardly seems peculiar. It was only to be expected.

Certainly the BUF was a deliberate provocation in what Mosley believed was a developing revolutionary situation where he and his followers would be called on to maintain order against communist-led working-class insurrection. In a debate that took place in February i 933, he told James Maxton that when the communist revolutionary finally took to the streets, 'we will be there ... with fascist machine guns to meet him'.17 Demonstrating an ability to smash the left was a central part of the BUF's raison d'être and the organization was quite ready to provoke disorder in order to bring this home. James Hope's recent article, 'Blackshirts, knuckle-dusters and lawyers' is a useful demonstration of this point. The BUF, he concludes, 'embarked on a strategy of violence' and if violence was then turned against them, 'the blackshirts had no one but themselves to blame'. ${ }^{18}$

To what extent did Blackshirt militarism and violence backfire on Mosley? With few exceptions commentators have seen the stewards' performance at the Olympia rally on 7 June 1934 as a crucial turning point in the BUF's fortunes. The gratuitous display of brutality with large numbers of blackshirts seizing and beating hecklers, it is argued, successfully alienated respectable opinion and irredeemably associated the BUF with thuggery. ${ }^{19}$ There does seem little doubt that the occasion was used as an opportunity for the public display of blackshirt efficiency at dealing with the reds. In Richard

\footnotetext{
15 Mosley, My life, pp. 30 I, 303. $\quad{ }^{16}$ Skidelsky, Mosley, p. 358.

17 Nicholas Mosley, Rules of the game-beyond the pale: memoirs of Sir Oswald Mosley and family (London, I993), p. 275.

${ }^{18}$ John Hope, 'Blackshirts, knuckle-dusters and lawyers: documentary essay on the Mosley versus Marchbanks papers', Labour History Review, 65 (2000), pp. 4 ${ }^{\mathrm{I}} 5^{8}$.

${ }^{19}$ See, for example, Roger Eatwell, Fascism: a history (London, 1995), p. 185.
} 
Thurlow's words, they 'deliberately over-reacted' ${ }^{20}$ And undoubtedly many of those present were shocked by what they saw, including some close to Mosley. A. K. Chesterton, for example, returned home appalled by what he regarded as unnecessary violence, and confessed to his wife that he had actually hit a steward ('one of the Kinder'), who was busy kicking a prostrate heckler. He informed his wife that he was going to resign. ${ }^{21}$ Subsequently, Chesterton changed his mind and went on to become one of the architects of the BUF's anti-Semitism. Recent work by Martin Pugh has, however, called into question the extent to which the violence at Olympia actually offended respectable opinion, arguing that while some Conservatives condemned the BUF, others were equally vocal in their support. It is similarly argued that Olympia cost Mosley the support of the Rothermere press, but once again Pugh shows that this is an oversimplification, with support tailing off rather than abruptly ending. ${ }^{22}$ It is worth noticing here that many writers on the BUF routinely refer to, and thereby give credence to, Mosley's claim that Rothermere's support only ended as a result of pressure from Jewish advertisers. Benewick laid this particular myth to rest as long ago as I 969 when he showed the healthy state of Rothermere's advertising revenues at the time. ${ }^{23}$

Olympia as a turning point in the BUF's fortunes is less convincing than the fact that the crisis Mosley was preparing for, and that many others feared was upon them, failed to materialize. Interest in and support for the BUF declined as a consequence. Those elements within the Conservative Party who had seen the BUF as a possible bulwark in a period of social, economic, and political collapse were now reconciled to the National Government, although many of them still retained a certain affection for fascist regimes abroad. ${ }^{24}$

A good case can be made that in the first phase of the BUF's history, Mosley had successfully prepared the ground for its transformation into a mass movement. He had established friendly relations with sections of the Conservative Party and many of its supporters were sympathetic to his cause. He had formed an alliance with Lord Rothermere, so that for a while, the BUF received the enthusiastic support of an important section of the press. The argument that Rothermere misrecognized Mosley is beside the point in this regard; many German conservatives had misrecognized Hitler, but that had hardly stopped him taking power. If Mosley's expected crisis had materialized then there is every reason to believe that the Rothermere alliance would have been cemented. The crisis, however, failed to turn up, and the BUF remained confined to the margins. There was to be no mass defection of Conservative voters and supporters, middle class and working class, to the BUF. The German example was not to be repeated.

\section{I I}

At this point, discussion of the BUF's attitude towards violence inevitably overlaps with its embrace of anti-Semitism. Skidelsky, for example, sees the origins of Mosley's 'quarrel with the Jews' as being the interaction between the BUF's anti-Semitism and Jewish anti-fascism. While the BUF was always susceptible to anti-Semitism and,

20 Thurlow, Fascism, p. I 02.

21 David Baker, Ideology of obsession: A. K. Chesterton and British fascism (London, I996), p. I 28.

22 Martin Pugh, 'The British Union of Fascists and the Olympia debate', Historical Fournal, 42

( I 998), pp. 529-42. $\quad{ }^{23}$ Benewick, Political violence, p. I 02.

24 See, in particular, Richard Griffiths, Fellow travellers on the right (Oxford, I980). 
indeed, attracted anti-Semites, it was the attacks on the organization by the Jews that led to its adoption of anti-Semitism as part of its programme. The Jews, as Skidelsky puts it, 'must take some of the blame for what subsequently happened '. ${ }^{25} \mathrm{He}$ goes on to try and distance Mosley from events in the East End of London, where the BUF actively engaged in trying to create the conditions for a pogrom. Certainly, the popular antiSemitism that existed in the East End was not created by the BUF, but the organization did its very best to exploit the situation. According to Skidelsky what went on in the East End had little to do with the BUF but was the work of what was almost an autonomous movement under the leadership of Mick Clarke. Its only connection with the rest of the organization was via Mosley himself. ${ }^{26}$

Skidelsky's argument has been given some qualified endorsement by others researching in the field. Colin Holmes, for example, has argued that some of the BUF's hostility towards the Jews 'was a response to violence initiated by the Jews, and in this sense Mosley and the BUF were as much sinned against as sinning'. ${ }^{27}$ Even Thomas Linehan has asserted that it was left-wing hostility that helped push the BUF 'in the direction of aggressive populist street campaigning and militant, open anti-Semitism ' ${ }^{28}$ The most comprehensive attempt to establish that the BUF 'was primarily the victim of offensive political violence, rather than its prime instigator' has undoubtedly been Stephen Cullen in an important article, 'Political violence: the case of the British Union of Fascists' that appeared in the Fournal of Contemporary History in I $993 \cdot{ }^{29}$ How adequate are these accounts?

According to Nicholas Mosley, anti-Semitism was always 'intrinsic' to the BUF. ${ }^{30}$ When preparing to launch the organization Mosley had considered making opposition to the alleged conspiracy of 'international Jewish bankers' part of its programme and was only dissuaded by Harold Nicolson from adopting this 'Nazi note'. ${ }^{31}$ Sometimes Mosley restrained the anti-Semites his movement attracted, sometimes he joined in with them. In the BUF's early days a sort of political schizophrenia was the result. On i 8 November i933, for example, The Blackshirt challenged opponents to find any hint of anti-Semitism in any BUF publication, while, elsewhere in that same issue it printed the doggerel verse

The oily, material, swaggering Jew

The pot-bellied, sneering, money-mad $\mathrm{Jew}^{32}$

Of course, such anti-Semitic sentiments were by no means confined to fascists and could easily be passed off as a reflection of the pervasive anti-Semitism of the time. What changed was that after a period of prevarication, Mosley himself, the Leader, openly embraced anti-Semitism and made it the cornerstone of his politics. Most accounts have him making a public declaration of his conversion at the Albert Hall in October i 934. Why did he take this step?

It has been suggested that it was an act of calculated, cynical expediency, that he was not himself an anti-Semite, never believed in the Jewish conspiracy but determined that

${ }^{25}$ Skidelsky, Mosley, pp. I6, 38 I. $\quad{ }^{26}$ Ibid., p. 327.

27 Colin Holmes, Anti-Semitism in British society, I876-1939 (London, I979), p. I 76.

${ }^{28}$ Linehan, East London, p. 8.

${ }^{29}$ Stephen Cullen, 'Political violence: the case of the British Union of Fascists', Fournal of Contemporary History, 28 ( I 993), pp. 245-67.

${ }^{30}$ Nicholas Mosley, Rules, p. 347.

${ }^{31}$ Gisela Lebzelter, Political anti-Semitism in England, I9I8-I939 (London, I978), p. 9I.

${ }^{32}$ W. F. Mandle, Anti-Semitism and the British Union of Fascists (London, I968), p. 5. 
it was politically useful to adopt anti-Semitism. More convincing is the explanation put forward by Robert Benewick, if only in passing, in his I 969 history of the BUF; ' Mosley had to construct a rationale to account for the failure of his movement. ${ }^{33}$ Rather than accept that the BUF had been confined to the margins because the situation in Britain was not conducive, that he had, in fact, made an enormous, indeed, in terms of his political career, fatal error of judgement, Mosley explained away failure, both to himself and his followers, as the fault of the Jews. The BUF had come up against a mighty power, international Jewry, that the British people were completely unaware of. This explained their defeat and made all the more heroic, all the more urgent, the struggle that lay before them. When Mosley asked A. K. Chesterton to investigate the power and influence of the Jews in contemporary Britain one suspects he knew exactly what he was going to get even if he pretended surprise. As Mosley told his Albert Hall audience in October I 934: 'I have encountered things in this country which, quite frankly, I did not believe existed. And one of these is the power of organised Jewry, which is today mobilised against Fascism. ${ }^{\prime 34}$ According to Chesterton, in his official BUF biography of Mosley, the Leader had discovered 'that there is no great financial, industrial or commercial trust or combine which was not dominated by the Jew, whether acting in person or by proxy ... Every vitiating and demoralising factor in our national life was Jew-influenced where it was not Jew-controlled.' It was this that inspired the BUF's 'crusade against Jewry'. And Chesterton goes on to quote Mosley himself, boasting that even three years before, 'anti-Semitism was unknown as a strong force in Great Britain. Today in any audience in Britain, the strongest passion that can be aroused is the passion against the corruption of Jewish power.' Who was responsible for this? Mosley had no doubts: 'the Jew himself has created anti-Semitism - created it as he has always done by letting people see him and his methods. Even Hitler was not anti-Semitic before he saw a Jew. ${ }^{35}$ These, it is worth emphasizing, are not hostile quotations, but those chosen by his official BUF biographer to celebrate the man. It is inconceivable that Mosley had not read and agreed to this portrayal of himself as an anti-Semite, as the Leader of an anti-Semitic movement.

Mosley, of course, has, since I940, denied that he was anti-Semitic, that while some of his followers were, he was above such crude, vulgar politics. He succeeded in satisfying himself in this matter by simply redefining the term. He was not opposed to Jews as such, but rather to what they did. This was mere sophistry because implicit in his argument was the belief that there was something about the Jews that made them do what they did. So much so that the BUF proposed to expel the majority of British Jews from the country while those few allowed to remain were to be deprived of British citizenship. They were not compatible with a healthy British nation. In effect, the BUF combined an ethnocentric stance with the politics of the Jewish conspiracy. ${ }^{36}$

Some authorities have been successfully misled by Mosley's sophistry in this respect. This would seem to have been the case with Skidelsky, but even J. D. Brewer accepts that there was a conflict in the BUF between the rational and the irrational. The example he gives of this conflict is the contrast between abstract arguments about Jewish connections with international finance and East End abuse of 'Jewish vermin'. To accept the Jewish world conspiracy as the rational side of British fascism is to concede

\footnotetext{
${ }^{33}$ Benewick, Political violence, p. I52. $\quad{ }^{34}$ Holmes, Anti-Semitism, p. I 77.

35 A. K. Chesterton, Oswald Mosley: portrait of a leader (London, n.d.), p. I 26.

${ }^{36}$ Holmes provides the best account of this, see Anti-Semitism, pp. I 79-8o.
} 
too much to the movement's own apologists. ${ }^{37}$ Mosley was later to claim that he had always considered the idea of an international Jewish conspiracy to be so much nonsense, but, as with his denial of anti-Semitism, this should not be taken seriously. Within a few pages of this assertion in My life, he identifies the source of his quarrel with the Jews as their determination to drag Britain into war with Germany. The conspiracy is denied, but its activities and the danger it posed are insisted upon. This was, he insists, a struggle that the Jews began, forcing him, in the interests of peace, to use methods against them that he would not normally have employed and which might have been repugnant to his character. ${ }^{38}$

One last point with regard to the BUF and violence is worth making. In the East End of London, the BUF preached the politics of the pogrom. For all of Mosley's personal charm, sophistication, wit, and good humour, this was what the BUF was about at street level. As Grisela Lebzelter has pointed out, attacks on the Jews

were not just elements of rowdy street-corner agitation in which unhappily Jews were involved, but amounted to a systematic attack on the Jews as such, designed to pillory them as outcasts of society. The totality underlying this Jew-baiting becomes apparent in the lines chanted by Fascist groups parading up and down the street in Jewish quarters: 'We gotta get rid of the Yids', 'We want Jewry's Blood' or 'Roll on the Pogrom'. It also transpired in the following rhyme, printed in a Fascist weekly publication:

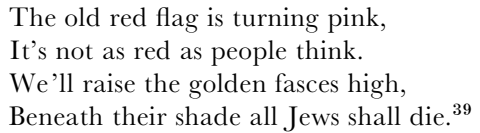

Even Cullen acknowledges something of this, quoting Mick Clarke in the aftermath of Cable Street: 'East London's big pogrom is not very far away now. The people who have caused the pogrom ... are the Yids ... by God there is going to be a pogrom. ${ }^{{ }^{40}}$ The gap between Mosley and Clarke was one of language rather than one of intention, and Mosley's own attempts to suggest otherwise, both at the time and later, were selfserving. Mosley's dream of a fascist nation had, as Richard Thurlow points out, been reduced 'to the reality of a minority anti-Semitic sub-culture in some areas of the East End of London'. ${ }^{41}$ Thomas Linehan's study of the BUF in the East End has carried our understanding of that sub-culture to a new level. ${ }^{42}$

The question of violence cannot be left without reference to the growing body of work investigating anti-fascism in the r 930 os and r 940 os. A number of useful books and local studies have appeared, establishing the extent to which anti-fascism was a mass movement, a focus of organization for much of the left. In many ways discussion has taken place within the parameters established by the memoirs of two leading antifascists, both members of the Communist Party, although seriously at odds with each other: Phil Piratin and Joe Jacobs. In his Our flag stays red, very much an official party autobiography, Piratin presented the heroic version of events in the East End in the I 930s, emphasizing the need not just to fight the fascists on the streets but actively to undermine their undoubted support among sections of the working class by organizing around social and economic issues. ${ }^{43}$ Joe Jacobs's Out of the ghetto presented a far more critical view of Communist policy, arguing that a reluctant party leadership had to be

37 Brewer, Mosley's men, p. 4.

39 Lebzelter, Political Anti-Semitism, p. $4 \mathrm{I}$.

41 Thurlow, Fascism, p. I I 8.

43 Phil Paratin, Our flag stays red (London, I948).
38 Mosley, My life, pp. $34 \mathrm{I}^{\mathrm{I}-2}$.

40 Cullen, 'Political violence', p. 263.

42 See Linehan, East London. 
pushed into confronting the police and the fascists at Cable Street, by pressure from below. ${ }^{44}$ Certainly, Communist opposition to fascism looks increasingly conditional, a proposition demonstrated by the abandonment of anti-fascism once the Hitler-Stalin Pact was signed. Mosley's peace campaign, with its insistent anti-Semitic counterpoint, went ahead without any Communist harassment. While not paying enough attention to Communist agitation around social and economic issues, Jacobs's memoir did have the considerable merit of removing the Communist Party's role from the realm of heroic myth and helped open it up to historical investigation.

Since then, three important books, Nigel Copsey's Anti-fascism in Britain, David Renton's Fascism, anti-fascism and Britain in the I940s, and Tony Kushner and Nadia Valman's edited volume, Remembering Cable Street, have appeared. Copsey's book examines anti-fascism in Britain from the i 920 s through to the Anti-Nazi League of the 70 and 8os. Of particular interest is his discussion of the opposition to the BUF in the I930s. He emphasizes the extent to which anti-fascism became a mass movement in this period, capable of mobilizing tens of thousands of people on the streets. On 9 September I 934, for example, over i oo, ooo people demonstrated against fascism in Hyde Park, an indication of 'the extent to which popular anti-fascist feeling amongst ordinary Londoners had been mobilised'. Copsey argues that the BUF's embrace of antiSemitism actually succeeded in 'widening the base of opposition to domestic fascism'. He is particularly successful in charting the development of Communist Party policy. ${ }^{45}$

David Renton's monograph focuses on the attempted resurrection of British fascism by Mosley and his followers in the immediate post-war years. While only briefly commenting on the BUF in the r93os, it is in many ways an exemplary study that highlights the need for a similar volume on the earlier period that examines fascism and anti-fascism in tandem. ${ }^{46}$ Also of considerable interest is Kushner and Valman's collection that includes papers on fascism and anti-fascism by Thomas Linehan, Julie Gottlieb, David Renton, Richard Thurlow, and others. Tony Kushner's own chapter, " "Long may its memory live!": writing and rewriting "the Battle of Cable Street", is an outstanding historiographical essay. ${ }^{47}$ There have also been a number of valuable local studies of fascism and anti-fascism in Oxford, Newcastle, the Medway towns, Aberdeen, and Manchester and Nelson. ${ }^{48}$

One last factor worth noticing here is relations between the BUF and the police, and the anti-fascists and the police. A recent study of civil liberties by K. D. Ewing and C. A. Gearty argues quite convincingly that the left, and, in particular, the Communist Party, was subject to consistent harassment by the police. The National Unemployed Workers'

${ }^{44}$ Joe Jacobs, Out of the ghetto (London, 1978).

45 Nigel Copsey, Anti-fascism in Britain (London, 2000), pp. 34, 42.

${ }^{46}$ David Renton, Fascism, anti-fascism and Britain in the I940s (London, 200o). See also his The rough game: fascism and anti-fascism (Stroud, 200 I).

47 Tony Kushner and Nadia Valman, Remembering Cable Street: fascism and anti-fascism in British society (London, 2000). Another valuable discussion of the battle of Cable Street is provided by Peter Catterall in 'The battle of Cable Street', Contemporary Record, 8 (I994), pp. I05-32.

${ }^{48}$ David Renton, Red shirts and black: fascists and anti-fascists in Oxford in the 1930s (Oxford, I 996); David Turner, Fascism and anti-fascism in the Medway towns, 1927-I940 (Kent, I 993); Nigel Todd, In excited times: the people against the Blackshirts (Tyne and Wear, I995); A. Rigby, Fascism in Aberdeen: street politics in the I930s (Aberdeen, I978); Neil Barrett, 'The anti-fascist movement in south-east Lancashire, I933-1940: the divergent experiences of Manchester and Nelson', in Tim Kirk and Anthony McElligott, eds., Opposing fascism: community, authority and resistance in Europe (Cambridge, I999). 
Movement seems to have been especially targeted. The BUF was never subjected to such treatment, at least, not until r940. While senior police officers, including the Commissioner, Sir Philip Game, certainly regarded the BUF as a threat to public order, at a lower level there seems to have been some sympathy and more partiality towards the Blackshirts. Mosley was careful never to involve his movement in direct conflict with the forces of law and order. Instead, the BUF loudly trumpeted its support for the police. In i 934, for example, when a policeman was shot in Sussex, Blackshirts joined in the search for the culprit. This concern to maintain friendly relations with the police seriously calls into question the notion that Mosley would have confronted the police at Cable Street except that he was due to marry Diana Mitford in Berlin. There was never any real likelihood of the BUF becoming involved in physical clashes with the police, partly because of Mosley's chosen strategy and partly because of the extent to which they relied on the police for protection. Certainly, elements within the police force were susceptible to Mosley's charms, giving the fascist salute at Cable Street and joining in the anti-Semitic abuse. ${ }^{49}$

Another area in which some important research has been carried out in the last few years concerns the relationship between the BUF and women. Martin Durham led the way with a number of publications: a chapter in The politics of marginality in I990, an article in the Fournal of Contemporary History in i 992, and, finally, a book-length study, Women and fascism published in I998. Women and fascism was, in fact, a general account of the relation, discussing not just the BUF, but also, briefly Italian fascism and Nazism, and at greater length the more recent British far right. While a more extended study of the BUF would have been useful, at the very least Durham established that the organization had a more complex attitude towards, and relationship with, women than often assumed. As he observed, contrary to the conventional wisdom, 'the BUF, rather than denouncing feminism claimed to be compatible with it'. Moreover, 'it was a movement in which women were highly active'.${ }^{50}$ This is an important corrective, but Durham would have done well to emphasize the limitations of the BUF's gender politics, in particular its opposition to any meaningful women's liberation, whatever its success in involving women in its activities. More recently, Durham's interesting account has been extended by Julie Gottlieb's outstanding Feminine fascism: women in Britain's fascist movement, 1923-1945. As she notes, 'the appearance of gangs of militant British fascist women provide a striking contrast to the prevalent notions of women's history during the inter-war period as a return to ideals of female domesticity and the

${ }^{49}$ K. D. Ewing and C. A. Gearty, The struggle for civil liberties: political freedom and the rule of law in Britain, 19I4-1945 (Oxford, 2000). Tony Kushner and Nadia Valman, 'Introduction: minorities, fascism and anti-fascism', in Kushner and Valman, Remembering Cable Street, p. 8. For Mosley's wedding and Cable Street see also Julie Gottlieb, 'Women and fascism in the East End', in the same collection, pp. $44^{-5}$.

${ }^{50}$ Martin Durham, 'Women and the British Union of Fascists, 1932-1940', in Kushner and Lunn, eds., Politics of marginality; Martin Durham, 'Gender and the British Union of Fascists', Fournal of Contemporary History, 27 ( 1992 ), pp. 51 3-29; Martin Durham, Women and fascism (London, 1998). See also Stephen Cullen, 'Our women for Mosley: women in the British Union of Fascists, I 932-1 940', Oral History, 24 ( I 987), pp. 49-59; David Mayall, 'Rescued from the shadows of exile: Nellie Driver, autobiography and the British Union of Fascists', in Kushner and Lunn, eds., Politics of marginality; and Hilda Kean, 'Some problems of constructing and reconstructing a suffragette's life: Mary Richardson, suffragette, socialist and fascist', Women's History Review, 7 (I998), pp. 475-93. For an interesting comparison see Glen Jeansonne, Women of the far right (Chicago, 1997), on the American far right between the wars. 
retreat of feminism'. The BUF not only claimed to support equality of the sexes, but also regularly stood women candidates in elections. Gottlieb discusses Mosley's appeal to women, the crucial limitations of women's participation in the fascist movement, the involvement of veteran suffragettes (Mary Richardson, Mary Allen, and Norah Elam), and fascist women's experience of internment during the war. She makes absolutely clear that fascist women were every bit as racist as fascist men, although highlighting particular aspects of 'the anti-Semitic discourse'. Altogether this is a provocative, stimulating piece of scholarship. It is somewhat ironic that the best account of the relationship of interwar political parties to women should be a study of the BUF. ${ }^{51}$ Biographies of the two fascist Mitford sisters, Unity and Diana, are revealing on the involvement of upper-class women with fascism, both domestic and foreign. ${ }^{52}$

This brings us to the last aspect of the BUF to be considered: the reasons for its political failure. A recent collection, The failure of British fascism, edited by Mike Cronin, chronicles the extent of fascism's failure from the British fascists of the I 920 s through to the contemporary British National Party. ${ }^{53}$ Certainly no British fascist organization has successfully made the transition from the first phase of development to the second, from a hardcore into a mass movement. What is particularly interesting about the BUF, however, is that it was not established by some aspiring street politician but by a member of the British upper class (two monarchs had attended Mosley's first wedding!) who had been in the House of Commons for over a decade and had served as a junior minister in a Labour government. Mosley could confidently have expected to continue his parliamentary career, although whether he was a future leader of the Labour Party, as some have suggested, seems more problematic. Instead, via the New Party, he embraced fascism. He abandoned a conventional political career in order to don the blackshirt. Why? His decision was based on what he believed was an imminent crisis that would wreck the old parties, sweep away traditional political loyalties, and result either in communism or fascism coming to power. He believed that the rise of Nazism was about to be replicated in Britain. What went wrong?

This was a subject to which Mosley was to devote considerable thought. In his memoirs, he argues that it 'would be possible to show on a graph in almost every case that the rise in unemployment coincided with major political change' as far as Europe was concerned. The problem that he confronted was that on the Continent, 'the degree of crisis - either in terms of unemployment or social disintegration, or both - was much more severe than in Britain'. Unemployment in Britain 'never reached half the crisis level prevailing in other countries where things happened'. When he launched the BUF in October 1932 unemployment had reached its peak and things temporarily took a turn for the better, 'but I remained convinced that crisis would eventually return in aggravated form ... on which I rested my whole action'. Instead, the BUF found itself operating in circumstances of limited economic recovery and falling unemployment, circumstances that guaranteed failure for such a movement. Mosley argued that the BUF's achievements even in these unfavourable conditions were such that 'it cannot be doubted we should have won in Britain if the crisis had deepened'. ${ }^{54}$ That the BUF

\footnotetext{
51 Julie V. Gottlieb, Feminine fascism: women in Britain's fascist movement, 1923-1945 (London, 2000), pp. 3, I30-I.

52 David Pryce-Jones, Unity Mitford: a quest (London, I 976); Jan Dalley, Diana Mosley (London, I 999). Also of considerable interest is Anne de Courcy's The viceroy's daughter (London, 2000), for Mosley's first wife and her sisters, both of whom he had affairs with.

${ }^{53}$ Cronin, The failure. $\quad{ }^{54}$ Oswald Mosley, My life, pp. 277-9, 3 Iо.
} 
could have made the transition to mass movement if the economic situation had seriously deteriorated does seem well within the realm of possibility. Whether it would have become strong enough to take power is another matter. More likely is the prospect of it pulling British Conservatism to the right and strengthening the hand of those who wanted a settlement with Nazi Germany. Mosley is more convincing as a junior partner of British Conservatism than as a British Führer.

By the time it became clear that the BUF was not going to command the political stage, Mosley had acquired an unhealthy taste for the role of fascist leader. This, together with the ideological sustenance provided by anti-Semitism, and the belief that fascism was a movement whose time had come, not just in Britain, but throughout Europe, was to sustain his 'illusions of grandeur' through the r93os, into internment and beyond.

Controversy still surrounds Mosley's arrest on 23 May i 940 and the subsequent mass arrest of BUF members and supporters. According to Diana Mosley, herself arrested on 29 June (her sister Nancy was among those who demanded she be interned), this was all a dreadful mistake. All Mosley wanted was to be able to either rejoin his old regiment or to have been offered some work by the government. She consoled herself with the thought that at least his internment saved him from having to feel responsible for any of the Allies' war crimes. ${ }^{55}$ This is rewriting history in the grand manner. More convincing are the accounts of Mosley's intrigues put forward by Richard Griffiths in his Patriotism perverted: Captain Ramsay, the Right Club and British anti-Semitism, 1939-1940, a book that really leaves the Mosleys' apologetics in tatters. ${ }^{56}$ Further evidence of Mosley's illusions of grandeur have been provided by the recent biography of one of his erstwhile lieutenants, John Beckett. Mosley attempted a reconciliation when they were both interned, offering Beckett a place in his provisional government. When Beckett refused, he was told he had been placed on the 'to be shot' list. ${ }^{57}$ Moreover, the release of the internees somewhat predictably saw a revival of fascist activity, although in hardly favourable circumstances. ${ }^{58}$

\section{V}

The debate over Irish fascism has as its starting point whether or not there ever was such a phenomenon. Maurice Manning, in his still unsurpassed study, The Blueshirts, argued that while Eoin O'Duffy's National Guard had the appearance of being fascists, they had none of the substance. They were, in fact, respectable Irish conservatives, who had merely adopted some of the symbolic trappings of European fascism as was fashionable

55 Diana Mosley, Loved ones, p. 205.

56 Richard Griffiths, Patriotism perverted: Captain Ramsay, the Right Club and British anti-Semitism, 1939-1940 (London, I998). See also Richard Thurlow, "The "Mosley Papers" and the secret history of British fascism, I939-1940', in Kushner and Lunn, eds., Traditions of intolerance, and Richard Thurlow, 'The evolution of the mythical British fifth column, I939-i946', Twentieth Century British History, I o, (1999), pp. 67-85.

57 Francis Beckett, The rebel who lost his cause: the tragedy of fohn Beckett MP (London, I 999), pp. $167-8$.

58 See Tony Kushner, 'The paradox of prejudice: the impact of organised anti-Semitism in Britain during an anti-Nazi war', in Kushner and Lunn, eds., Traditions of intolerance. Also Claire Hirshfield, 'The tenacity of tradition: truth and the Jews, I877-I957', Patterns of Prejudice, 28 ( 1994$)$, pp. 67-85. 
at the time. The Treaty of 1922 and the divisions it occasioned still dominated Irish politics and the blueshirt was merely an article of apparel temporarily adopted by one of the protagonists in this peculiarly Irish quarrel. ${ }^{59}$ This view is wholeheartedly endorsed in most of the standard histories of modern Ireland. Joe Lee, for example, considers the Blueshirts to be 'traditional conservatives' for whom fascism was 'far too intellectually demanding'. The shirt and the salute were really only as far as they went. All he finds are 'largely incidental similarities' with European fascism. Indeed, if anything, he considers that Fianna Fáil adopted even more of the trappings of fascism than the Blueshirts, although, he makes clear, it was no more fascist. ${ }^{60}$ Similarly, while Alvin Jackson acknowledges that the Cumann na nGaedheal leadership 'flirted with paramilitarism and the trappings of fascism', nevertheless 'O'Duffy's fondness for outrageous rhetoric and elaborate uniforms was more 'O'Connellite than Hitlerian' and his proposed Dublin march 'closer to Clonfert in I843 than Rome in I922' ${ }^{61}$ Ireland, from this point of view, remained unsullied by the great clash of ideologies taking place on the Continent.

This argument has always had something of special pleading about it, but it was nevertheless given substance by the particular history of Irish fascism. What we see in Ireland is fascism successfully manifesting itself as a mass movement, but nevertheless remaining in a clearly subordinate relationship with Irish conservatism. It is the nature of this relationship with conservatism that has led those historians and political scientists who have examined the Blueshirts to call into question the very existence of an Irish fascism. One point worth making here is the scandalous neglect by historians of modern Irish conservatism. It is really incredible that there is still no scholarly biography of independent Ireland's first Taoiseach, William Cosgrave, nor of Kevin O'Higgins, nor any other minister in the Cumann na nGaedheal government. There is still no scholarly study of the Cumann na nGaedheal itself. Indeed, the Blueshirts, who have received little enough attention, have nevertheless received more than have the Irish conservatives. It is also worth noting that John Regan's recent The Irish counter-revolution, ${ }^{192 I-1936}$ is an important step in the remedying of this neglect. ${ }^{62}$

The key to understanding the Blueshirt phenomenon is the shock that the Cumann na nGaedheal leadership felt at being deprived of power by de Valera's Fianna Fáil, their exaggerated fear of the likely consequences of this and their realization that Fianna Fáil was successfully consolidating its position. In these circumstances, they not only intrigued with the British government against Fianna Fáil, but also embraced, for a while at least, an Irish fascism as a way of restoring their political fortunes. Moreover, many of their supporters, hard hit by de Valera's Economic War with Britain, saw the dynamic militancy of the National Guard as a way of hitting back against those they held responsible. These were the circumstances that led Cosgrave, Mulcahy, Blythe, and their colleagues to attach themselves to the self-proclaimed Irish Mussolini, Eoin O'Duffy. There should be no doubt that if the Blueshirts had been successful, Irish parliamentary democracy would have been replaced by some kind of authoritarian

\footnotetext{
59 Manning, The Blueshirts. See also Richard Finnegan, 'The Blueshirts of Ireland during the I930s: fascism inverted', Eire-Ireland, 24 ( 1989), pp. 79-99. For British fascism and Ireland see R. M. Douglas, 'The swastika and the shamrock: British fascism and the Irish question, I9I8-I945', Albion, 29 (1997), pp. 57-75.

${ }^{60}$ J. J. Lee, Ireland, I9I2-1985 (Cambridge, I 989), pp. I 8 I -2.

${ }_{61}$ Alvin Jackson, Ireland, I798-1998 (Oxford, I 999), pp. 300-1.

${ }^{62}$ John Regan, The Irish counter-revolution, I92I-I936 (Dublin, I999).
} 
government reflecting the balance of forces between the conservatives and fascists in the movement. At the very least their political opponents would have been proscribed, trade unions taken over, civil liberties suspended, and Ireland's small Jewish population deprived of citizenship and/or expelled. These were things that Irish conservatives were prepared to countenance in order to be rid of de Valera, some only with considerable reservations, others without any problem at all. When it became clear that Fianna Fáil's hold on power was too strong, that the Blueshirts were becoming increasingly embroiled in public disorder and that O'Duffy himself was a political liability, the conservatives terminated the alliance. This effectively reduced Irish fascism to a residual hardcore. Irish conservatives did not abandon fascism because of its authoritarianism or its antiSemitism, but because it failed to deliver the goods.

How does the most recent account of the Blueshirts, Mike Cronin's The Blueshirts and Irish politics contribute to our understanding of developments? In some ways the book is a missed opportunity. Rather than replace Manning's account as a general history of the movement, Cronin instead examines a number of particular aspects, a procedure that gives his book a tentative, provisional character. What are his specific arguments? Cronin shows that the Blueshirts became a mass movement (over 6o,ooo members at their greatest strength) in response to the Economic War. It was the considerable hardship occasioned by the conflict with Britain that motivated the movement's rank and file. This was the movement's raison d'être as far as its mass support was concerned. Of course, this was not a particularly new idea with regard to Blueshirt motivation, but Cronin convincingly argues for its centrality. This leads on to another of his substantive arguments: that there was a significant difference between the ideology of the Blueshirt leadership and that of their followers. Cronin argues that an important section of the leadership did have a fascist agenda. He explores the ideas of the intellectuals around O'Duffy, the likes of Michael Tierney, James Hogan, Ernest Blythe, and W. B. Yeats, and successfully establishes their fascist provenance. The concerns of these men were not, however, the concerns of the rank and file. This is hardly surprising. Indeed, it is a probable feature of all fascist movements that make the transition from hardcore to mass movement. Whereas the hardcore are attracted by the ideology and dynamism of fascism, the mass membership is only recruited by conditions of social, economic, and political crisis which the fascists promise to resolve. For many people in Ireland in the early i 930 , the Economic War was such a crisis.

Cronin interviewed fifteen former members, a very slight sample. From their testimony he identifies the Economic War, land annuities, and free speech as their principal motivations. He displays a certain naïveté in his discussion of this oral evidence, particularly on the question of free speech. For fascists to claim to be defending free speech while they are in opposition is not unusual. Mosley did the same. How they would behave once they were in power is, of course, a different matter. It is clear from Cronin's own account that an O'Duffy regime would have been a one-party corporate state that would not have tolerated opposition. How then does Cronin characterize the Blueshirts? He follows Roger Griffin in opting for the label of 'parafascist'. This does not seem particularly helpful. It obscures the crucial relationship between fascism and conservatism. When fascist groups became mass movements they recruited the bulk of their new supporters from the traditional conservative parties. A crisis, in the Irish case the Economic War, led the supporters of traditional conservatism, Gumann na nGaedheal supporters, to turn their back on constitutional politics and rally to fascism, in the shape of the Blueshirts. At this point the relationship between the 
fascists and the conservative elite became crucial. In Italy and Germany, the conservatives joined coalition governments with the fascists; in Ireland they formed a political party, Fine Gael, with them. De Valera's determination to see off the fascist challenge made this unstable alliance shortlived. ${ }^{63}$

What of the opposition to the Blueshirts? The opposition on the streets came from the republican movement and from the, much weaker, political left. For many republicans the conflict was a continuation of the Civil War, but for those influenced by the left it was a battle against the Irish manifestation of international fascism. ${ }^{64}$ More important was the stand taken by de Valera's government, a stand admirably chronicled by Eunan O'Halpin's recent Defending Ireland: the Irish state and its enemies since 1922. ${ }^{65}$ Mike Cronin has also contributed a useful chapter on the opposition to the Blueshirts to Tim Kirk and Anthony McElligott's collection, Opposing fascism: community, authority and resistance in Europe. ${ }^{6}$ The crucial moment was the government's decision to ban O'Duffy's proposed march on Leinster House on i 3 August I933. Clearly modelled on Mussolini's march on Rome (O'Duffy admitted as much himself), the demonstration would have inevitably resulted in serious street clashes with counter demonstrators, with unforeseeable consequences; all at a time when the government was not confident it could rely on the army and the police. De Valera moved decisively to ban both the march and, soon after, the National Guard itself. Although it was to reincarnate itself under various guises, it was clear that the government intended to defeat the Blueshirts by whatever means were necessary. Once it was apparent that the streets did not offer the way back to power, O'Duffy was to be dispensed with by his conservative allies. $\mathrm{He}$ resigned as leader of Fine Gael in September i 934, hoping to split the party, only to find himself successfully marginalised, at least for the time being.

\section{V}

This was not the last of Eoin O'Duffy however. He was to attempt a political comeback in 1936 by leading a volunteer 'brigade' to Spain to fight alongside the military insurgents against the Republic. It is quite remarkable that while in most European countries public opinion was seriously divided over the Spanish Civil War, with often strong support for the Republic, in Ireland it was overwhelmingly for Franco. So much so that Ireland was the only country to send a significant force of genuine volunteers, the Irish Brigade, to fight for the rebels. While Irishmen did go to fight in the International Brigades, it was O'Duffy's volunteers who were, at least initially, the heroes of the moment, setting forth to fight for the Catholic faith against the forces of Godless Communism. Now, after being neglected for many years, O'Duffy's military adventure, has been the subject of two substantial studies. Both Robert Stradling's The Irish and the Spanish Civil War, 1936-1939 and Fearghal McGarry's Irish politics and the Spanish Civil War look at the International Brigaders as well as at O'Duffy's men, indeed McGarry's

${ }^{63}$ Mike Cronin, The Blueshirts and Irish politics (Dublin, I997).

${ }^{64}$ For the Irish left in the I93os see in particular Richard English, Radicals and the republic (Oxford, I994). For an alternative view see Manus O'Riordan, 'Communism in Dublin in the I 93 os: the struggle against fascism', in H. Gustav Klaus, Strong words, brave deeds: the poetry, life and times of Thomas O'Brien (Dublin, I994).

${ }^{65}$ Eunan O'Halpin, Defending Ireland: the Irish state and its enemies since I922 (Oxford, I999).

${ }^{66}$ Mike Cronin, 'The Blueshirts in the Irish free state, I932-I935: the nature of socialist republican and governmental opposition', in Kirk and McElligott, eds., Opposing fascism. 
book offers a compelling view of the impact of the Spanish War in Ireland that goes well beyond concern with the volunteers from either camp.

Let us look at Stradling's contribution first. This is, at least in part, an attempted rehabilitation of O'Duffy's volunteers, an attempt to rescue the Irish Brigade from the derision to which it has been subjected pretty much since it returned home to Ireland. Stradling puts this down to their association with 'one word: fascism' and to the way in which O'Duffy has become 'virtually unspeakable in Irish historical discourse'. This is only partly true. While O'Duffy has been an embarrassment to post-i945 Irish conservatism, a reminder of its fascist flirtation, more to the point was the, to say the least, poor performance of his volunteers once they had arrived in Spain. Stradling's own account of their exploits only reinforces the view that they were completely unprepared for the ferocious character of the Spanish War. Indeed, far from going to Spain to fight, and, if necessary, die in the crusade against International Communism, O'Duffy seems to have been primarily concerned with restoring his political fortunes back home. He had hoped to take part in a victory parade, perhaps participating in some mopping up operations, but was certainly not prepared for heavy fighting in which large numbers of his followers would be killed. The incorporation of the Irish volunteers into the Spanish Foreign Legion was positively grotesque in the circumstances.

When O'Duffy refused to continue the attack at Titulcia in March I937 (an offence for which a Spanish officer would have been shot), despite only minimal casualties (one dead), it became clear to Franco that his Irish allies were militarily worthless. Now, of course, it is somewhat problematic for someone who has never heard gunfire outside of the cinema to criticize the performance of men huddled in trenches in fear of imminent mutilation or death. Nevertheless, at the very least, O'Duffy's military adventure was not a success. It certainly did not provide the vehicle for reviving the fascist cause in Ireland. Stradling attempts to get round this by arguing that the volunteers were in the main not fascist, but can best be regarded as 'premature anti-Stalinists'. Certainly, he has some interesting points to make about the motivation of O'Duffy's volunteers, but the fact remains that however they arrived there, they were fighting in support of Franco's military dictatorship under the leadership of Ireland's aspiring fascist Duce.

Stradling goes on to discuss the experience of the two-hundred-odd Irish volunteers who fought in the International Brigades. What becomes absolutely clear is that their involvement in the conflict was of a different order from that of the Irish Brigade. While he corrects Manus O'Riordan's official account that was written very much in the heroic, celebratory mode, he still concludes quite inescapably that at the battle of Jarama, for example, the International Brigades' performance was 'among the most impressive achievements of modern warfare'. He goes on: 'Stripped of myth, drained of sentiment and cleansed of propaganda, it remains an unsurpassed record of heroism mixed with disaster but above all tragedy.' Of the eighty Irishmen who took part in the battle thirty were killed and twenty-five wounded. ${ }^{67}$

Despite the self-consciously provocative nature of some of his conclusions, Stradling has certainly made a worthwhile, if flawed, contribution. It is, however, overshadowed by McGarry's book that decisively sets both groups of volunteers in the context of Irish

67 Robert Stradling, The Irish and the Spanish Civil War, I936-I939 (Manchester, I999), p. i64. See also Frank Thomas (ed. Robert Stradling), Brother against brother (Stroud, i 998), for an account of the Spanish Foreign Legion. For the official Communist view of the Irish participation in the International Brigades see Michael O'Riordan, The Connolly column (Dublin, I979). 
politics and in the process redefines that context. He positions O'Duffy as a truly dedicated follower of fascism (although always of a clericalist variety). Here was a man who not only cultivated links with international fascism, but, even after the Spanish fiasco, was able seriously to contemplate leading Irish volunteers to fight alongside the Italians in Ethiopia and even more incredibly alongside the Germans in Russia in 1943 ! McGarry chronicles the experiences of O'Duffy's volunteers, but is particularly good on the International Brigaders. His is an account that takes on board both the idealism of the volunteers and the Stalinist purposes to which that idealism was put. This is an honest warts and all reckoning. Whereas O'Duffy hoped to revive his domestic fortunes in Spain, the left-wing volunteers (Communist Party, Republican Congress, Irish Republican Army) went, at least in part, because of despair at ever being able to build a socialist movement in Ireland. In Spain, they might have been able to make a difference.

Most impressive is McGarry's account of the Irish Christian Front, a mass movement that for a short while dominated Irish politics. In September I936 a Christian Front rally in Cork attracted over 40, ooo people, who heard Monsignor Patrick Sexton blame the Spanish War on 'a gang of murderous Jews in Moscow'. The following month another huge meeting was held in Dublin, pledging enthusiastic support for Franco. As McGarry shows, many of the clergy were openly partial to authoritarian government and anti-Semitism with these ideas informing much of the popular devotional literature of the time. A key figure was Father Denis Fahey, a prominent theologian, whose antiCommunist and anti-Semitic tract, The rulers of Russia, was made use of by the BUF in Britain. Quite appropriately, Franco's eventual victory was celebrated with a Te deum performed by Archbishop Byrne in the Pro-Cathedral on 24 April i 939. Present were leading Fine Gael politicians, O'Duffy, and diplomatic representatives from Germany, Italy, Portugal, Chile, and Spain, but no Fianna Fáil representatives. This identifies an important gap in McGarry's account. He successfully establishes the popularity of Franco's cause in Ireland, but is less successful in explaining how de Valera negotiated the challenge this posed, how he preserved Fianna Fáil's ascendancy. ${ }^{68}$ One last point: McGarry's promised biography of Eoin O'Duffy is a book very much to look forward to. ${ }^{69}$

The Spanish Civil War also had an important impact on politics in Northern Ireland. Here, Harry Midgley, a Protestant member of the Northern Ireland Labour Party, who represented the mainly Catholic Dock constituency at Stormont, took an uncompromising stand in defence of the Republic. While he emphasized that the conflict was a struggle against fascism, his clerical and nationalist opponents emphasized that it was a struggle for religion. A ferocious campaign to unseat Midgley, a conscientious MP, was let loose, a campaign that culminated in his defeat in the January r 938 Stormont general election. While Spain was not the only factor in his downfall, it is clear that the nationalists preferred to let in a Unionist rather than see the return of the anti-Franco Midgley. ${ }^{70}$ The problems that working-class Irish Catholics posed for the British labour

\footnotetext{
68 Fearghal McGarry, Irish politics and the Spanish Civil War (Cork, I 999). For Irish anti-Semitism in the I93os, see Dermot Keogh, Jews in twentieth century Ireland (Cork, I 998).

69 Fearghal McGarry, 'General O'Duffy, the National Corporate Party and the Irish Brigade', in Joost Augusteijn, Ireland in the I930s (Dublin, I999), provides a foretaste of his O'Duffy biography.

${ }^{70}$ Graham Walker, The politics of frustration: Harry Midgley and the failure of Labour in Northern Ireland (Manchester, I985), pp. 85-I I . For British fascism and Northern Ireland see James
} 
movement with regard to Spain have been explored by Tom Buchanan and the opportunities this offered to the BUF by Thomas Lineham. ${ }^{71}$

What of the Spanish Civil War and British politics? Tom Buchanan has produced an excellent overview, Britain and the Spanish Civil War that builds upon the strengths of his earlier study, The Spanish Civil War and the British labour movement. ${ }^{72}$ More specifically, what of British involvement in the International Brigades? The literature in this area can be seen as dividing into two camps: the celebratory and the condemnatory. A good example of the celebratory mode is Bill Alexander's British volunteers for liberty, I936-1939, published as recently as I 986 . This is a heroic recounting of the exploits of the British volunteers in the great battle for democracy and against fascism. It is the official Communist Party version of events written by a former battalion commander. ${ }^{73}$ The condemnatory mode is exemplified by R. Dan Richardson's Comintern army, a study of the International Brigades as such rather than of British participation. For Richardson, the Brigades were a Comintern operation carried out in the interests of Russian foreign policy, a cynical Stalinist manoeuvre. Stalin's commitment to anti-fascism was quickly to be shown for what it was by his I 939 pact with Hitler. Both versions have much to say that makes an essential contribution to our understanding of both the International Brigades and of British participation. ${ }^{74}$ James Hopkins's new book, Into the heart of the fire: the British in the Spanish Civil War, manages to combine the strengths of both approaches.

The British volunteers were, in the main, idealists who went to Spain to fight for freedom; this much is incontestable. But at the same time it has be to acknowledged that the International Brigades were a mobilization of international working-class solidarity that was ruthlessly and cynically exploited by the Stalinist apparatchiks controlling the Comintern. They exercised their control by the same secret police methods that they used to rule the Soviet Union. The British Communist leadership was a party to this. Hopkins's triumph is successfully to document both sides of the story to tremendous effect. The idealism, the disillusion, the courage, the ruthlessness, the self-sacrifice, and the self-seeking are all put into perspective. Moreover, he does justice to those volunteers who fell foul of the Communist Party and found themselves maligned and victimized, men like Jack Carson, Alec Marcovitch, and George Wattis. Part of the problem he faced in accomplishing this was the way in which the Communist Party had over the years tried to control the history of the International Brigades. One particular example is provided by the way lifelong Communist Nan Green could still deny any knowledge of secret police activity in Spain forty years after the event only for the newly opened Russian archives to show that she had herself been the subject of an investigation after being denounced by Bill Rust. The level of duplicity is quite amazing. But this is not an anti-Communist tract. Hopkins also does justice to the likes of Ralph Bates, Christopher Caldwell, and others. He is relentlessly honest. Without a doubt, he has written the best

Loughlin 'Northern Ireland and British fascism in the inter-war years', Irish Historical Studies, 29 (I985), pp. $537^{-52}$.

${ }^{71}$ See Tom Buchanan, The Spanish Civil War and the British labour movement (Cambridge, I991), and Lineham, East London.

${ }^{72}$ Buchanan, The Spanish Civil War; Tom Buchanan, Britain and the Spanish Civil War (Cambridge, I997).

${ }^{73}$ Bill Alexander, British volunteers for liberty, I936-1939 (London, I986).

${ }^{74}$ R. Dan Richardson, Comintern army: the International Brigades and the Spanish Civil War (Lexington, I982). 
book on British participation in the International Brigades and it is difficult, at this point in time, to see how it will be surpassed. ${ }^{75}$

${ }^{75}$ James K. Hopkins, Into the heart of the fire: the British in the Spanish Civil War (Stanford, I998). For an excellent regional study see Hywel Francis, Miners against fascism: Wales and the Spanish Civil War (London, I 984). See also Ian MacDougall, ed., Voices from the Spanish Civil War: personal recollections of Scottish volunteers in republican Spain (Edinburgh, I986). 